\title{
Nexus Between Literacy Education and Entrepreneurial Skill Acquisition of Artisans in Osun State, Nigeria
}

\author{
Dr. Eyitayo Olufumilayo Akinyemi \\ Department of Adult Education, Adekunle Ajasin University, Akungba Akoko. Ondo State, Nigeria
}

\begin{abstract}
The study was examined to look at the nexus between literacy education and entrepreneurial skills of artisans in Osun State, Nigeria. Two hundred and ten (210) artisans were drawn from three Senatorial districts of Osun State, Nigeria using stratified random sampling technique. Data collected were analysed using frequency counts, percentages, and Anova analysis. Findings showed that lack of patience to spend the stipulated years for training is the major problem hindering artisans' effectiveness in entrepreneurial skills, and those who did not acquire literacy education found it difficult to perform well. Findings also revealed that ability to be able to read and write had great impact on artisans' entrepreneurial skills acquisition, revealing there is a nexus between literacy education and entrepreneurial skill acquisition. It was therefore recommended that individual in the society need to acquire literacy education before embarking on any entrepreneurial skill acquisition for self and the development of their society.
\end{abstract}

Keywords: Artisans, entrepreneurial, literacy education, nexus, skill acquisition.

DOI: $10.7176 / \mathrm{JEP} / 10-11-10$

Publication date: April $30^{\text {th }} 2019$

\section{Introduction}

Literacy is the ability to read and write and understand written text. Literacy has been considered as a form which could not be separated from reading numeracy"; or one's ability to be able to read, write and manipulate numbers. Literacy can develop differently in individuals and is crucial for development in all areas of human endeavour, this could be in terms n social, economic, political, communication and many others.

Kruidenier (2002) opined literacy as the ability to practice reading and writing in specific situations to obtain or communicate specific information. (Guthrie \& Greaney 1999: Smith, 1995, 2000; Reder, 1994) observed literacy practices describe how individuals use reading and writing in various situations. Alberta Education viewed literacy as the ability, confidence and willingness to engage with language to acquire, construct and communicate meaning in all aspects of daily living. Language here is explained as a socially and culturally constructed system of communication. Literacy mean preparing learners to be critical and ethical consumers of information.

The development of literacy occurs not only in schools but in every aspect of daily activities. Human beings interact with others when there is conversation. We read maps, advertisements, newspaper, recipes, manuals and websites, also analyse and interpret large amount of media information, while we write poems, songs, reports, blogs and emails. Thus, literacy opens the door to the world. Literacy practice could occur in individual as emphasized by Smith, $(1995,2005)$ that individual use reading and writing in various situations like reading books, newspaper, magazines, writing letter or texts relating to one's job. Literacy is crucial for development. The level of a man's literacy could determine how successful he might be in life, revolving on his day to day activities. Literacy could play important role in making learning and execution of any entrepreneur effective, helps in relating well with members of the society.

Being able to read, write and do some calculations are important to the extent that Nigeria National Policy on Education (2014) lay emphasis on acquiring basic education for individual and national development. Adequate literacy skills are necessary for individual development to participate and function happily in one's community, it helps in maintaining better health through one's ability to understand and interpret health information, it also enables one to communicate easily with one's health instructor, this will help in detecting individual health problem so as to get quick treatment for any ailment, thus having great impact on the health of artisans trying to acquire skills for future income. Literacy is also important in other fields like agriculture, politics, commerce and industry, which helps in the development of individual and the society.

Literacy according to Odumuh (2010) in Olaniyi (2018) is the ability to acquire the knowledge of being able to read, write and do some numeracy with other experiences of life which will enable the adult learner adjust to his environment and making interaction with people around him to be convenient. Literacy education is designed to promote positive changes in the life of an individual to meet the demand of socio-economic demands of one's society. Literacy education is out- of- school education focused at meeting the needs and aspirations of people in the society. Literacy education for artisans is important because it will be of great benefit to individual and members of the society, it will dictate the quality of end products of their entrepreneurial skills. With the acquisition of literacy education, individual will be empowered to take proper decision about improving his 
productivity, think positively when it comes to issues relating to politics, social life and improvement or advancement in his/her standard of living. When artisans are able to improve the quality of their productivity, this will have positive effect on the rate of technological advancement of a country.

In summary, acquiring literacy education skills empowers an individual to think positively, take good decisions about life and the society, encourages him/her to take and improve on his productivity, this will help him socially, economically and politically.

\section{Literature Review}

Educators observed literacy can be a channel to developing critical thinking skills, as it is the foundation for success in every area of an individual life (Arnett, 2017). The future of everyone in the society is improved when someone is being helped to read and write effectively or acquire the basic skills. Literacy is important to economic development of individual and the well-being of a community, as acquisition of literacy education enhances the economy of a society. When effective literacy skills are acquired by an individual, it allows access to better educational employment opportunities, this helps in guiding against underemployment and experiencing poverty by an individual, (Kelowna, 2018).

Entrepreneurial skill is observed as business skills, which an individual acquire in order to make him function effectively in business as an entrepreneur to be self- reliant (Umumadi, 2014). Literacy enables an entrepreneur to identify, initiate, organize, and bring an idea to life, this could be in the act of inventing new products, services, process, strategy or market (Mkpa, 2014). Literacy helps in the acquisition of entrepreneurial skills for efficient and effective living. It gives individual more opportunity to exercise creative freedom, higher self-esteem, and a greater sense of control over one's own life. Education is observed to be the bedrock of the development of any country, any country that does not educate her people is bound to fail (Adamu, 2017).

Individual is able to contribute to the economic development of his society through the influence of literacy education that had helped in imparting necessary skills and attitude necessary for his/her daily activities (Anugwom, 2009). Literacy education aimed at bringing positive changes in character and learning as it plays important roles in all forms of development of an individual. It initiate important development; makes a person to be balanced by surviving every situation and contributing in a meaningful way in order for the society he belong to survive (Olaniyi, 2018). Literacy education can be focused towards the provision of functional education, cultural, political, and social and in all aspects of life of the participants. It could also be directed through its programmes at providing the participants that are not employed with those with skills that could make them to be employed (Imhabekhai, 2009).

Olaniyi, (2018) further stressed that literacy education is one of the professions that is capable of caring for the political, environmental, cultural, and socio-economic problems pertaining to the adults. Also, literacy education changes the psychological and social life of adults as it makes them realise the need not to lose hope but could learn and make it in life. Okpoko (2010) states that literacy education has been regarded as a means to development, when an individual is empowered through literacy, it then becomes an opener to members of their family, community, individual, nation, and the entire world. Olojede (2013) stressed acquisition and utilization of literacy education by an individual helps in generating income in order to make living convenient and enables ones choice to be heard when decisions are being made on social and political issues.

UNESCO (2014) stated literacy education is important as it assist every learner to acquire skills and knowledge necessary in daily activities, it helps learner easy communication in writing, personal security, selfconfidence, as the society will not be able to exploit or cheat someone, and employment opportunities which enables an individual to be free from unemployment, underemployment and poverty, freedom to vote and be voted for, boost ones economy, and operate machine for self-development. As opined by Kruidenier (2002), Literacy is important for acquiring skills, in the opinion of Nwafor (2009), literacy consist of making proper use of information, ideas, development of competences, rendering of services and becoming a good product for the society, but all these factors could be aided with the assistance of literacy education, thus showing there is a relationship between literacy education and artisans' entrepreneurial skills acquisition.

\section{Objectives of the Study:}

1. examine the perceived obstacles hindering artisans effective acquisition of entrepreneurial skills of artisans in Osun State, Nigeria.

2. ascertain the impact of literacy on entrepreneurial skill acquisition among artisans in Osun State, Nigeria.

3. examine the benefits of literacy education to individual welfare

\section{Research questions:}

1. What are the perceived obstacles hindering artisans effective acquisition of entrepreneurial skills?

2. What is the impact of literacy on entrepreneurial skills acquisition among artisans in Osun State? 
3. What are the benefits of literacy education to the welfare of an individual in the society?

\section{Research hypothesis}

There is no significant relationship between literacy and artisans' acquisition of entrepreneurial skills in Osun State, Nigeria.

\section{Methodology}

The research design used for the study was the survey design type. The population for the study constituted the artisans who were learning different skills in Osun State, Nigeria. The sample size for the study were 214 respondents accidentally selected from three local government areas of the three senatorial districts in Osun State. The main instrument that was used for the data collection was a structured questionnaire.

\section{Results}

Research question 1: What is the impact of literacy education on entrepreneurial skill acquisition among artisans in Osun state?

Table 1: Frequency and percentage summary on the impact of literacy on entrepreneurial skill acquisition among artisans in Osun state

\begin{tabular}{|c|c|c|c|c|}
\hline Items & & & ponse & \\
\hline & & Yes & No & Total \\
\hline One can read and write & Frequency & $\%$ & $\begin{array}{l}16 \\
92.5\end{array}$ & $\begin{array}{l}214 \\
7.5\end{array}$ \\
\hline 100.0 & & & & \\
\hline It took one more years than & Frequency & 136 & 78 & 214 \\
\hline $\begin{array}{l}\text { expected to learn skills because } \\
\text { one could not read and write. }\end{array}$ & $\%$ & 63.6 & 36.4 & 100.0 \\
\hline One's ability to read and & Frequency & 200 & 14 & 214 \\
\hline $\begin{array}{l}\text { write made skill acquisition to be } \\
\text { convenient }\end{array}$ & $\%$ & 93.5 & 6.5 & 100.0 \\
\hline One's ability to read and write & Frequency & 206 & 8 & 214 \\
\hline $\begin{array}{l}\text { made entrepreneurial activity } \\
\text { convenient }\end{array}$ & $\%$ & 96.3 & 3.7 & 100.0 \\
\hline One is able to buy and use good & Frequency & 195 & 19 & 214 \\
\hline materials for customers' work & $\%$ & 91.1 & 8.9 & 100.0 \\
\hline Literacy enables one to relate well & Frequency & 204 & 10 & 214 \\
\hline with customers & $\%$ & 95.3 & 4.7 & 100.0 \\
\hline Through literacy, one is able to & Frequency & 201 & 13 & 214 \\
\hline meet the needs of customers & $\%$ & 93.9 & 6.1 & 100.0 \\
\hline Literacy enables me to be / & Frequency & 198 & 16 & 214 \\
\hline effective in services to customers & $\%$ & 92.5 & 7.5 & 100.0 \\
\hline Literacy skills encourages one & Frequency & 183 & 31 & 214 \\
\hline $\begin{array}{l}\text { to mix with social groups for soft } \\
\text { loans }\end{array}$ & $\%$ & 85.5 & 14.5 & 100.0 \\
\hline Averaged Total & Frequency & 1936 & 900 & 214 \\
\hline & $\%$ & 89.4 & 10.6 & 100.0 \\
\hline
\end{tabular}

Field survey, 2018

It could be observed from Table 1 that the respondents $96.3 \%$ claimed ability to read and write made entrepreneurial activity convenient, while $3.7 \%$ disagreed with the statement. It could be opined from the observed distribution that the respondents have a positive attitude towards the impact of literacy on entrepreneurial skill acquisition with $89.4 \%$ confirming it, while $10.6 \%$ did not. Findings revealed that ability to read and write made entrepreneurial skill acquisition activity to be convenient among artisans in Osun State. 
Research Question 2: What are the perceived obstacles hindering artisans' effective acquisition of entrepreneurial skills?

Table 2: Frequency and percentage summary on the obstacles hindering artisans' effective acquisition of entrepreneurial skills

Items

\begin{tabular}{|c|c|c|c|c|}
\hline & & Yes & No & Total \\
\hline $\begin{array}{l}\text { Effective acquisition of } \\
\text { entrepreneurial skill was } \\
\text { hindered due to inability } \\
\text { to read and write }\end{array}$ & $\begin{array}{l}\text { Frequency } \\
\%\end{array}$ & $\begin{array}{l}178 \\
83.2\end{array}$ & $\begin{array}{r}36 \\
16.8\end{array}$ & $\begin{array}{r}214 \\
100.0\end{array}$ \\
\hline $\begin{array}{l}\text { Lack of sufficient money to } \\
\text { pay for one's training }\end{array}$ & $\begin{array}{l}\text { Frequency } \\
\quad \%\end{array}$ & $\begin{array}{l}161 \\
75.2\end{array}$ & $\begin{array}{l}53 \\
24.8\end{array}$ & $\begin{array}{c}214 \\
100.0\end{array}$ \\
\hline $\begin{array}{l}\text { Lack of interest in becoming } \\
\text { an artisan }\end{array}$ & $\begin{array}{r}\text { Frequency } \\
\%\end{array}$ & $\begin{array}{l}161 \\
75.2\end{array}$ & $\begin{array}{c}53 \\
24.8\end{array}$ & $\begin{array}{l}214 \\
100.0\end{array}$ \\
\hline $\begin{array}{l}\text { Inadequate method being } \\
\text { used by facilitators to } \\
\text { impact knowledge to } \\
\text { people on training }\end{array}$ & $\begin{array}{r}\text { Frequency } \\
\%\end{array}$ & $\begin{array}{l}167 \\
78.0\end{array}$ & $\begin{array}{l}47 \\
22.0\end{array}$ & $\begin{array}{c}214 \\
100.0\end{array}$ \\
\hline $\begin{array}{l}\text { When the facilitators } \\
\text { cannot read and write, } \\
\text { or do some calculations }\end{array}$ & $\begin{array}{c}\text { Frequency } \\
\%\end{array}$ & $\begin{array}{l}159 \\
74.3\end{array}$ & $\begin{array}{l}55 \\
25.7\end{array}$ & $\begin{array}{c}214 \\
100.0\end{array}$ \\
\hline $\begin{array}{l}\text { Lack of patience by trainee } \\
\text { to complete the number } \\
\text { of years expected to be } \\
\text { effective artisans }\end{array}$ & Frequency & $\begin{array}{r}181 \\
84.6\end{array}$ & $\begin{array}{c}33 \\
15.4\end{array}$ & $\begin{array}{c}214 \\
100.0\end{array}$ \\
\hline Average Total & $\begin{array}{c}\text { Frequency } \\
\%\end{array}$ & $\begin{array}{l}168 \\
78\end{array}$ & $\begin{array}{c}46 \\
22\end{array}$ & $\begin{array}{c}214 \\
100.0\end{array}$ \\
\hline
\end{tabular}

Field survey, 2018

Testing statement relating to the obstacles hindering artisans' effective acquisition of entrepreneurial skills was presented in Table 2. $83.2 \%$ of the respondents affirmed that effective acquisition of entrepreneurial skill was hindered due to inability to read and write' while $16.8 \%$ were of contrary opinion. Lastly, $84.6 \%$ which constituted the majority, the respondents confirmed lack of patience by trainee to complete the number of years expected to be effective artisans was an obstacle hindering effective acquisition of entrepreneurial skill, while $15.4 \%$ disagreed. Consecutively, the average summary showed that $78.0 \%$ of the respondents agreed on with the perceived obstacles hindering artisans' effective acquisition of entrepreneurial skills, while $22.0 \%$ indicated negative perception towards it. Findings revealed that lack of patience and inability to read and write are the major obstacles hindering effective acquisition of entrepreneurial skills by artisans in Osun State.

Research Question 3: What are the benefits of literacy education to the welfare of an individual?

Table 3: Frequency and percentage summary on the benefits of literacy education to individual welfare.

Items

Through literacy education, one is able to buy and use good materials for the work of customers

Literacy education encourages one to mix with social groups for soft loans.

Literacy education improves the social life of an individual
Response

Yes No Total

$\begin{array}{llll}\text { Frequency } & 183 & 21 & 214\end{array}$

$\begin{array}{llll}\% & 89.4 & 10.6 & 100.0\end{array}$

$\begin{array}{llll}\text { Frequency } & 168 & 46 & 214\end{array}$

$\begin{array}{llll}\% & 78.0 & 22.0 & 100.0\end{array}$

$\begin{array}{lccc}\text { Frequency } & 206 & 8 & 214\end{array}$

$\begin{array}{llll}\% & 96.3 & 3.7 & 100.0\end{array}$

Average Total

439

61

214

Field Survey, 2018 
Responding to the benefits of literacy education to the welfare of an individual, $89.4 \%$ of the respondents were of the view that literacy education enables one to buy and use good materials for the work of customers, while $10.6 \%$ of the respondents were of different view. $78 \%$ of the respondents agreed literacy education encourages one to mix with social groups for soft loans, while $22 \%$ disagreed with the statement. Also, $96.3 \%$ of the respondents agreed literacy education improves the social life of an individual, while $3.7 \%$ of the respondents disagreed with the statement. It could be concluded that

Research Hypothesis:

Ho: There is no significant relationship between literacy education and artisans' acquisition of entrepreneurial skill in Osun State, Nigeria.

Table 4: Anova Table showing the result of operationalization of the variables where literacy education and artisan acquisition of entrepreneurial skills were regressed.

Table 5: ANOVA Table

\begin{tabular}{|l|l|l|l|l|l|}
\hline Model & Sum of Squares & Df & Mean Square & F & Sig \\
\hline Regression & 14.002 & 1 & 14.002 & 12.022 & .001 \\
Residual & 124.617 & 214 & 1.165 & & \\
Total & 138.619 & 213 & & & \\
\hline
\end{tabular}

Source: Field survey, 2018

Analysis of variance (ANOVA) indicates information concerning the total variation in the dependent variable into addictive components in that analysis of variance is not interested in the relationship between literacy education and artisans' acquisition of entrepreneurial skills. The p-value of 0.001 is less than 0.05 which is the level of significance. Since the p-value is less than 0.05 , thus null hypothesis is rejected. Therefore, we reject the null hypothesis that there is no significant relationship between literacy education and artisans' acquisition of entrepreneurial skills.

Table 6: Regression table

\begin{tabular}{|ll|l|l|l|l|l|}
\hline \multirow{2}{*}{} & \multicolumn{2}{|l|}{ Unstandardized Coefficients } & Beta & T & Sig. \\
\cline { 3 - 4 } & B & Std. Error & & & \\
\hline \multirow{2}{*}{1} & (Constant) & 2.670 & .349 & & 7.651 & .000 \\
& Literacy education & .322 & .093 & .401 & 3.467 & .001 \\
\hline
\end{tabular}

Source: Field survey, 2018

There is need to examine the variable and by doing regression analysis. Thus, from the table above, regression equation for the model is given below:

Literacy education: $2.670+0.322 *$ artisans acquisitions skill. The regression confirms direct relationship between literacy education and artisans' acquisition of entrepreneurial skills. Also the parameter co-efficient of the independent variable (TE) is statistically significant at 5\% level is calculated t-value of 3.467.

\section{Discussion of Findings}

The purpose of the study was to establish the relationship between literacy education and entrepreneurial skill acquisition on artisans in Osun state, Nigeria. The study revealed that artisans' ability to read and write makes entrepreneurial skill acquisition activity convenient. This agrees with the finding of Mkpa (2014) that literacy enables an entrepreneur to identify, organize and bring an idea to life, which could be in the act of inventing new products, service, process, strategy or market. This shows the importance of literacy on artisans' entrepreneurial skill acquisition.

The study further revealed that effective acquisition of entrepreneurial skills was hindered due to their inability to read and write. This is in line with the finding of Adamu (2017) that education is the bedrock of the development of any country, any country that does not educate her people is bound to fail. Findings also reveals that lack of patience by trainee to complete the number of years expected for training is one of the obstacles hindering artisans effective acquisition of entrepreneurial skills. This finding is in agreement with Nwafor (2009) that acquisition of entrepreneurial skill is for efficient and effective living, it gives individual more opportunity to exercise creative freedom, higher self-esteem, and a greater sense of control over one's own life. Hence, for effectiveness of artisans in entrepreneurial skill acquisition, there are needs for them to be patient during training to acquire all the necessary knowledge expected to function as efficient entrepreneur later in life.

Findings also revealed literacy education improve the social life of an individual. This finding is also in agreement with the statement of UNESCO (2014) on the importance of literacy at assisting every learner to acquire skill and knowledge necessary in daily activities, it helps learners easy communication in writing, personal security, and self-confidence, as the society will not be able to exploit or cheat someone, freedom to vote and be voted for, boost ones economy, and function in every area in the society. 
The summary of findings from this study reveals there is a nexus between literacy and entrepreneurial skill acquisition on the welfare of artisans in Osun State, as the respondents agreed that literacy education has great impact on their acquisition of entrepreneurial skills, it enables one to relate well with customers and meet their personal needs.

\section{Conclusion}

The study revealed that effective acquisition of entrepreneurial skill was hindered due to inability to read and write, and lack of patience by trainee to complete the number of years expected to be effective artisans. The study revealed that literacy education have influence or great impact on artisan's effective acquisition of entrepreneurial skill in Osun State, Nigeria.

\section{Recommendations}

It is imperative for artisans to have patience to acquire all the necessary knowledge expected of them during training so as to be useful for themselves and their society in order to have the capacity to compete with the world market

Artisans are advised to have some elements of literacy education before going out to acquire knowledge on any skill to be self-reliant.

\section{References}

Adamu, A. (2017). Illiteracy rate in Nigeria is alarming, Vanguard September 21 www. vanguardngr.com Alberta Education, Literacy and Numeracy 1. Education.alberta.ca

Anugwom, E.E. (2009).Women education and work in Nigeria. Educational Research and Review Journal, (4)127-134. Retrieved October 4 ${ }^{\text {th }}, 2011$ from: http://www.academicjournals.org/ERR

Arnett, A.A.(2017). 5 trends in literacy education for 2017. Deep Dive. www.educationdive.com

Federal Republic of Nigeria (2014). National Policy on Education. $6^{\text {th }}$ edition. Nigerian Educational Research $\&$ Development Council (NERDC). Abuja

Gruthrie \& Greaney,1999; Smith, 1995; Reder, 1994; Literacy education in Adult Basic Education NCSALL Review of Adult Learning and Literacy. 3 (4)

Imhabekhai, C.I. (2009). Programme development and management in adult and non-formal education. Ibadan Amfitop Ltd. Ibadan

Kelowna, (2018). Literacy report card for the federal electoral district of Kelowna lake country, downloaded from http:// www.dataangelica

Kruidenier, John (2002), Literacy education in Adult Basic Education: National centre for the study of Adult learning and literacy. (3) www.ncsall.net

Mkpa, A.M. (2014), Education for global competiveness in job creation: Inclusion of entrepreneurship in Nigeria higher education; challenges and prospects. International journal of Educational Research, 13(1), 1-1

Nwafor, H.A., (2009). Acquisition of innovative and entrepreneurial skills in Basic Science Education for job creation in Nigeria.

Olaniyi, F.O. (2018). Perceptions of adult learners towards literacy education for better economic development in Oyo State, Nigeria. Journal of Education in Developing Areas (JEDA). March. 26 (1), pp 240-254.

Okpoko, A. (2010). Positioning adult literacy to empower rural women for sustainable livelihood in Nigeria. A paper presented at the National Conference on Repositioning Adult and Literacy Programmes in Nigeria. Organised by Nigeria National Council for Adult Education (NNCAE), at the University of Ibadan, Nigeria. $\left(7^{\text {th }}-9^{\text {th }}\right.$ December, 2010).

Olojede, A.A. (2013). Evaluating access to adult basic literacy skills as determinant of sustainable development in selected rural communities in Oyo and Ondo States, Nigeria. Sky Journal of Educational Research. 1(1), pp1-8.

Reder (1974). Origin of western literacy. Four lectures delivered at the Ontario Institute for Studies in Education, Toronto, Monograph Series. 14.

Umunadi, E.K. (2014) Acquisition of entrepreneurial and technical education skills for global competitive and job creation, International Journal of Education Research, 13(1), 128-144

UNESCO (2014). Training manual for facilitators in non-formal education, Abuja: UNESCO. 


\section{ADEKUNLE AJASIN UNIVERSITY, AKUNGBA-AKOKO FACULTY OF EDUCATION, DEPARTMENT OF ADULT EDUCATION.}

\section{QUESTIONNAIRE ON 'NEXUS BETWEEN LITERACY AND ENTREPRENEURIAL SKILL ACQUISITION OF ARTISANS IN OSUN STATE, NIGERIA'}

\section{Dear Respondents,}

SECTION A

Kindly respond to the following questions.

\section{PERSONAL BIODATA}

1. Occupation: Trading ( ), Farming ( ), Business Centre Operation ( ), Furniture ( ) Fashion Designing ( ), Mechanic ( ), Bricklayer ( ), Iron Bender ( ) Others ( )

2. Education: Primary ( ), Secondary ( ), Others ( )

SECTION B

Tick 'YES' or 'NO' in response to each of the questions below:

(i) Impact of literacy education on entrepreneurial skill acquisition among artisans in Osun State.

1. One can read and write

YES $\left.{ }^{(}\right) \quad(\stackrel{)}{)}$

2. It took one more years than expected to learn skills because one could not read and write.

3. One's ability to read and write made skill acquisition to be convenient

4. One's ability to read and write made entrepreneurial activity convenient

5. Literacy enables one to relate well with customers.

6. Through literacy, one is able to meet the needs of customers.

7. Literacy enables one to be effective in services to customers.

8. Literacy skills encourages one to mix with social groups for soft loans.

(ii): What are the perceived obstacles hindering artisans' effectiveness in entrepreneurial

1. Effective acquisition of entrepreneurial skill was hindered due to inability to read and write.

2. Lack of sufficient money to pay for one's training.

3. Lack of interest in becoming an artisan.

4. Inadequate method being used by facilitators to impact knowledge to people on training.

5. When the facilitator cannot read and write, or do some calculations.

6. Lack of patience by trainee to complete the number of years expected to be effective artisans.

(iii): What are the benefits of literacy education to individual welfare?

1. One is able to buy and use good materials for customer's work

2. Literacy skills encourages one to mix with social groups for soft loans.

3. Lack of sufficient money to pay for one's training.

4. Literacy improve the social life of an individual. 